\title{
Encyclopedia of Local Historical Figures as a Learning Source of Independent Local Content for Students of Junior High School in South Kalimantan
}

\author{
Mansyur \\ History Education Department \\ Faculty of Teacher Training and Education \\ Universitas Lambung Mangkurat \\ Banjarmasin, Indonesia
}

\begin{abstract}
Generally source of local content books for teachers and students in junior high school in South Kalimantan still has many limitations. Based on the researcher's observations, the limitation lies in the abundance of presented materials, the language difficult to understand, and only few illustrations/images that are presented. An alternative to learning resources that can be developed is needed. Encyclopedia is a book that gathers information or descriptions of a variety of things in the field of art and science. The entries are arranged alphabetically or by following a certain system in logical science. Explanation of themes in encyclopedia is accompanied by interesting, relevant and informative pictures. Local historybased informative encyclopedia as a source of local content learning with the history material of Banjar is categorized good and worthy of being used as a source of learning. Therefore, the availability of the encyclopedia is considered very essential as reference materials to supplement the knowledge of teachers and students in particular subjects of local content
\end{abstract}

Keywords-encyclopedia, figures, local history, banjar

\section{INTRODUCTION}

The Indonesian government has designed a curriculum in an effort to increase the quality of education. The curriculum is used at school as a learning process. The learning process that is implemented is not detached from the learning source that supports such as textbooks, reference books, libraries, electronic media, and educators. One of the learning sources used most often is in the form of book. Book has an important role in the learning process as stated in the Regulation of National Education Minister No. 2/2008 that educational books are aimed at providing experience, knowledge, skills to students about life in different fields, society, culture, and natural surroundings as well as of god almighty.

Based on the results of observation at junior high school in South Kalimantan, educators generally stated that learning sources used during teaching and learning process are packages of books, educators' guide/manual, e-book, and the internet. Although several books used in school are already quite effective, some school subjects require good books which are elusive for educators or students. Limitations of learning sources cause students' low interest for studying. Consequently, learning sources/reading sources need to be added. The learning sources should have difficulty level that suits students' ability and language which is easy to understand.

Based on the results of observation towards the sources of the books owned by educators and students, limitations of the books are that there are too many materials are presented in the books, the language is difficult to understand, and there are only few of illustrations/images. There should be alternative learning source that can be developed freely. Encyclopedia is a book that collects description or explanation about various things in the fields of art and science. The entries are arranged alphabetically or by following a certain system in logical science. Description entry is accompanied by interesting, relevant and informative pictures [1].

\section{DiscusSION}

In recent years, the growth of science and technology enable our nation to do rapid improvement. The existing of the Internet make it easier for students to search for information and data easily. A wide range of information can be found in the internet. However, the technological development direction towards modernity seems to lead to reduced interest and self initiative to study the local history among students. Consequently, many students have bad insight and poor knowledge on nationalism as well as the pride of the history in their own area. For instance, many students seem to start to forget the spirit of nationalism and local figures who had fought against the invaders who have occupied this nation, namely the heroes of Indonesia at the local level. In fact, many students only know the figures as indicated on a street name, building or specific areas without knowing the the figures' background and struggle.

Indonesia is a great nation, a nation that knows and appreciates its heroes who have struggled for the nation, especially at the local level. One way to promote nationalism and heroism is by making encyclopedia of Banjarese historical figures in South Kalimantan in particular. In general, 
encyclopedia contains knowledge. An encyclopedia is a form of reference that is presented in a (or several volumes) book that contains information about all or a branch of the science, technology, arts or other disciplines. Encyclopedia might contain or discuss only one aspect or discipline and it is called a specialized encyclopedia, such as the free botanical education encyclopedia, encyclopedia of world architecture, the free medical, free transportation.

Encyclopedia can be used as a source of study because it is packaged in a clear and interesting way, so it is expected to increase students' interest in learning. With high learning interest, the learning process will be more conducive and can take two directions. One of the materials can be about the characters who play a role in local history of Banjar. The packaging of local historical figures at South Kalimantan generally can be developed as a source of learning in the form of encyclopedia. Encyclopedia has advantages compared to other print learning sources since it presents complete and fundamental information in a about a problem in the field of Science [2].

According to Tantriadi [3], encyclopedia can also provide visualization that can attract the interest of students in the learning process. In addition, encyclopedia is one source of information which can expand readers' insights [4], and it presents various pictures which can help readers to understand the given explanation more easily [5]. Based on the tests performed by Cholifatur [6], it was found out that encyclopedia could increase the students' understanding of the materials being studied.

Informativelocal history-based encyclopedia as a source of learning local content on history of Banjar is categorized good and worthy of being used as a learning source. Therefore, the availability of the encyclopedia is considered very essential as reference material to supplement the students' knowledge of particular subjects of local content.

The development of media publications sometimes do not use and think of an effective way, to introduce or publish information on local heroes. Many books or media related to the history and nationalism are less interested and do not really pay attention to effort to add public's insights. One of the barriers is aesthetic value and media promotions and publications that are not well thought by the publisher and author. To this end, the existence of encyclopedia as part of students' reference must be followed with visual interest and a high aesthetic value. The goal is to attract readers for viewing, reviewing and instilling the values of the book.

An author of an encyclopedia should understand the basic concept of a reference book so that the completeness and accuracy of the information presented can be used appropriately by readers. It summarizes the information in a comprehensive manner, such as organizing the materials alphabetically by subject headings or alphabetical order. Encyclopedia usually consists of a set of articles about certain subject separately and independently. The presentation of the subject headings is arranged alphabetically for easy use. Encyclopedia is compiled based on classification subject, or a combination of the classification of the subject and alphabetical order. A good encyclopedia is usually supplemented with examples, photos, pictures or interesting illustrations to clarify the notion of an entry [7]

In making encyclopedia, we need to pay attention to the characteristics of an encyclopedia First, themes are arranged alphabetically or following scientific system. Second, theme explanations are accompanied by interesting, relevant and informative drawings with the themes discussed. Third, themes have a high or very complete level of complexity. Fourth, there must be comprehensive discussion in each theme. Next, all themes are presented consistently with the subject area of the encyclopedia. Finally, the encyclopedia is equipped with a glossary, index and bibliography. The examples of encyclopedia titles are the botanical encyclopedia, the encyclopedia of architecture, and the space encyclopedia [8]

\section{CONCLUSION}

The encyclopedia as part of local content publications provides educational value to the public to enhance the appreciation of Banjarese local heroeswith media interest, as well as to improve nationalism by knowing the history of Banjar. The values of heroism and struggle are the ideal choices which have been accepted and recognized as well as contain a commitment of the community. In the social dimension, the values of local communities are the norms, standards or principles of action that direct or guide people's behavior. The heroes and warriors of Banjar have a great and successful participation for Indonesia into the gate of freedom, of course, guided by certain values, nationalism, patriotism and citizenship.

The value of nationalism can be described as a spirit or sense of belonging to a nation. Elaboration of the value itself is the existence of a willingness to make sacrifices for the sake of nation. The values of patriotism can be interpreted as a spirit or sense of being willing to hand over the properties even risking lives to maintain independence. The value of citizenship is seen in understanding that everyone has certain rights and obligations as a citizen. To become a citizen, or the urban or rural community, means having the social right to participate in the process of social life. Banjarase younger generation especially in junior high school level is currently undergoing a process of degradation of the values of heroism.

They idolize an imaginary figures who often appear in the show, film and the like more that the Banjarese local figures. In the meantime, they are less acquainted with the figures of the Banjarese heroes and warriors. If they know them, they might only know them as a name or a character enshrined into the name of the streets, buildings, and so on. The unpopularity of heroism values related to Banjarese figures nowadays might occur due to several factors, namely lack of knowledge and understanding of the young generation on the values of heroism and lack of the discussion of the values contained in local material in school textbooks, especially related to local Banjarese heroism. 


\section{REFERENCES}

[1] Sugijanto, Pusat Kurikulum Perbukuan Depdiknas, (Jakarta: Puskurbuk Balitbang Kemdikbud, 2008

[2] I. Yuslina, "Koleksi Rujukan sebagai Sumber Belajar Bagi Siswa."retrieved fromi http://repository.um.ac.id/images/stories on 19 April 2014

[3] Y. Tantriadi, "Pembuatan Ensiklopedia Interaktif Tata Surya untuk Siswa SMP" dalam Caliptra, Jurnal Ilmiah Mahasiswa Universitas Negeri Surabaya, vol. 2, 2013

[4] G. Vanessa, "Pembuatan Ensiklopedia Hewan Punah dan Terancam Punah Berbasis Web", dalam Calyptra, Jurnal Ilmiah Mahasiswa Universitas Negeri Surabaya, vol. 2, 2013.
[5] Riko, "Persepsi Pemustaka terhadap Layanan Perpustakaan pada Kantor Perpustakaan dan Kearsipan Kota Singkawang", Tesis pada Universitas Indonesia, Depok, 2010

[6] F. C. Rosyidha, "Pengaruh Penggunaan Ensiklopedi Bahan Praktikum kelas XI Terhadap Motivasi dan Hasil Belajar Siswa Kelas XI MAN Lab UIN Yogyakarta, Skripsi UIN Sunan Kalijaga, Yogyakarta, 2015.

[7] D. Supardi, Anatomi Buku Sekolah di Indonesia Problematika Penilaian, Penyebaran dan Penggunaan Buku Pelajaran, Buku Bacaan dan Buku Sumber, (Yogyakarta: Adicita Karya Nusa), 2001

[8] A. Prastowo, Panduan Kreatif Membuat Bahan Ajar Inovatif, Yogyakarta : Diva Press, 2012. 